Tourasse and Darfeuille

\title{
1 T1TAdb: the database of Type I Toxin-Antitoxin systems
}

3 Nicolas J. Tourasse* and Fabien Darfeuille*

5 Univ. Bordeaux, CNRS, INSERM, ARNA, UMR 5320, U1212, F-33000 Bordeaux, France.

6 *corresponding authors. E-mail: nicolas.tourasse@inserm.fr; fabien.darfeuille@inserm.fr

8 Running head: Database of type I toxin-antitoxin systems

9

10 Keywords: toxin-antitoxin system, database, genome, antisense RNA, RNA structure, bioinformatics 

perpetuity. It is made available under aCC-BY-NC-ND 4.0 International license.

Tourasse and Darfeuille

Abstract

Type I toxin-antitoxin (T1TA) systems constitute a large class of genetic modules with antisense RNA (asRNA)-mediated regulation of gene expression. They are widespread in bacteria and consist of an mRNA coding for a toxic protein and a noncoding asRNA that acts as an antitoxin preventing the synthesis of the toxin by directly basepairing to its cognate mRNA. The co- and posttranscriptional regulation of T1TA systems is intimately linked to RNA sequence and structure, therefore it is essential to have an accurate annotation of the mRNA and asRNA molecules to understand this regulation. However, most T1TA systems have been identified by means of bioinformatic analyses solely based on the toxin protein sequences, and there is no central repository of information on their specific RNA features. Here we present the first database dedicated to type I TA systems, named T1TAdb. It is an open-access web database (https://d-lab.arna.cnrs.fr/t1tadb) with a collection of $\sim 1,900$ loci in $\sim 500$ bacterial strains in which a toxin-coding sequence has been previously identified. RNA molecules were annotated with a bioinformatic procedure based on key determinants of the mRNA structure and the genetic organization of the T1TA loci. Besides RNA and protein secondary structure predictions, T1TAdb also identifies promoter, ribosome-binding, and mRNA-asRNA interaction sites. It also includes tools for comparative analysis, such as sequence similarity search and computation of structural multiple alignments, which are annotated with covariation information. To our knowledge, T1TAdb represents the largest collection of features, sequences, and structural annotations on this class of genetic modules.

\section{Introduction}

Toxin-antitoxin (TA) systems are encoded within small genetic loci found in most of bacterial genomes including those of pathogens. They are usually composed of two adjacent genes: a stable toxin and a labile antitoxin that inhibits the toxin's action or expression and whose depletion rapidly leads to cell death or growth arrest (Harms et al. 2018). Six types of TA systems have been described so far depending on the nature and mode of action of the antitoxin (reviewed in (Page and Peti 2016)), 
Tourasse and Darfeuille

1 and a seventh type has been recently proposed (Wang et al. 2021). While the toxin is always a protein,

2 the antitoxin can be either a protein (types II, IV, V, VI, and VII) or an RNA (types I and III).

Type II TA systems are by far the most well studied class of TA systems. Extensive data for these systems are available in two databases, TADB 2.0 (Xie et al. 2018) and TASmania (Akarsu et al. 2019), which also include limited data for other types of TA systems. These databases also provide a tool (TAfinder and TASer, respectively) to scan and predict TA systems (Akarsu et al. 2019; Xie et al. 2018). Other TA-specific resources include BtoxDB (Barbosa et al. 2015), a database of TA protein structural data, and RASTA_Bacteria (Sevin and Barloy-Hubler 2007), a tool to scan for toxins and antitoxins in bacterial genomes (unfortunately, both are no longer maintained). Overall, none of these existing databases contains expanded data about type I TA (T1TA) systems. The RNA

11 families database Rfam (Kalvari et al. 2021) currently contains more than 600 antitoxin RNA entries that belong to 13 known T1TA families. Rfam is a useful resource that provides, for all families, sequences, alignments, structures, covariance models (that can be used to search genomes), phylogenetic trees, and links to Wikipedia articles. However, it contains no data for the associated toxin mRNAs of the T1TA systems, as Rfam is focused on non-coding RNAs.

A T1TA system consists of a relatively short mRNA (150 to 400 nucleotides long) coding for a small protein (20-60 amino acids in length) whose expression is toxic to the host cell and an antisense RNA (asRNA; 60-200 nt in length) that serves as a counteracting antitoxin to prevent the synthesis of its cognate toxin by directly basepairing to the mRNA. Numerous aspects of T1TA systems have been studied including RNA structure, toxin-antitoxin interaction, regulatory gene expression mechanisms (transcription, translation, degradation, processing), mechanism of action of the toxin, and function in cell physiology (Masachis and Darfeuille, 2018). While TA systems located on plasmids have been demonstrated to contribute to plasmid maintenance (via the mechanism of postsegregational killing, (Greenfield et al. 2000; Gerdes et al. 1986)), the roles of TA systems al. 2020). 
bioRxiv preprint doi: https://doi.org/10.1101/2021.04.14.439843; this version posted August 13, 2021. The copyright holder for this preprint (which was not certified by peer review) is the author/funder, who has granted bioRxiv a license to display the preprint in perpetuity. It is made available under aCC-BY-NC-ND 4.0 International license.

Tourasse and Darfeuille

A few T1TA systems have been experimentally characterized, but hundreds have been

2 identified by bioinformatic analyses (Arnion et al. 2017; Fozo et al. 2010). By exhaustive amino acid sequence homology searches using PSI-BLAST and TBLASTN run with customized parameters,

Fozo and coworkers identified $\sim 900$ sequences of ORFs coding for homologs of known type I toxin peptides from 7 families in 95 bacterial species and 229 strains (Suppl. Table S5 in (Fozo et al. 2010)).

6 In addition, through searches based on characteristics of T1TA loci (such as tandem repeats and 7 hydrophobicity) they proposed more than 2,000 novel toxin ORFs in hundreds of genomes (Suppl.

Table S8 therein). These analyses were essentially protein-based and did not investigate the mRNA

features. Based on thermodynamic local free energies, they could detect the position of asRNA genes

of a few known families, but the coordinates spanned only a 100-nt window and the precise start and

11 end boundaries of the full-length molecules were not obtained (Suppl. Table S9 therein). Most of the

identified T1TA loci are not yet annotated in genome records, and it is necessary to have an accurate annotation of the complete mRNA and asRNA molecules to understand the co- and posttranscriptional regulation of T1TA systems, which is determined by RNA sequence and structure (Masachis and Darfeuille 2018). Thus, there is a deep need for a central repository of T1TA systems that would include RNA information. In this work, we have built a database, named T1TAdb, which gathers all described and predicted loci of T1TA systems and where the mRNA and asRNA the procedure used to identify mRNAs and asRNAs.

\section{Results and Discussion}

We have developed T1TAdb, the first database dedicated to T1TA systems. It can be accessed by users through a graphical web interface. A preliminary, development version was put on-line in January 2019 and has been regularly updated, corrected, and improved (https://d-

25 lab.arna.cnrs.fr/t1tadb). The database provides sequence, secondary structure, and genomic information on T1TA loci. In its current, initial version, it is limited to bacterial genomes that were 

perpetuity. It is made available under aCC-BY-NC-ND 4.0 International license.

Tourasse and Darfeuille

1 reported in the literature to carry T1TA systems. It contains 1894 loci belonging to 24 families from

2218 bacterial species and 493 strains. Data on toxin mRNA, antitoxin asRNA, and toxin peptides

3 were taken from the current literature. Only a small number of loci have been experimentally

4 characterized and the bulk of the data in T1TAdb are mainly based on the results of genome-wide

5 bioinformatic studies. This includes the AapA/IsoA family that has been extensively curated in about

6100 genomes of Helicobacter and Campylobacter (Arnion et al. 2017) and the large number of loci

7 found in hundreds of genomes in the study of (Fozo et al. 2010). The analyses by (Fozo et al. 2010)

8 did not investigate the mRNA genes and recovered only partially the asRNA genes. Therefore, in our

9 work, a major effort to build the T1TAdb database has been devoted to the annotation of the genomic

10 locations of the toxin mRNA and antitoxin asRNA corresponding to each toxin ORF of known family

11 reported by (Fozo et al. 2010), in order to reconstruct the complete loci.

Annotation of toxin mRNA and antitoxin asRNA genomic localization based on RNA structural features

The genomic regions defining the mRNAs and asRNAs were predicted using RNAMotif (Macke et al. 2001) and RNASurface (Soldatov et al. 2014), respectively. RNAMotif is used to identify regions that can adopt a predefined secondary structure, while RNASurface predicts regions that are structurally more stable than the rest of the genome. A comparison of the asRNA coordinates predicted by RNASurface with those experimentally determined by transcriptome analyses revealed a good agreement. RNASurface predictions were usually within 10 bases of the experimental coordinates, at both the 5' and 3' ends, for diverse T1TA families in Helicobacter pylori and Escherichia coli, but larger differences were more often observed for Enterococcus faecalis (Supp.

23 Tables S2-S6). Moreover, the 5' ends of mRNAs predicted by our RNAMotif structural descriptors showed a similar accuracy. In the case of T1TA systems, a complete TA locus was obtained when a pair of mRNA and asRNA could be predicted, with lengths, orientations, complementary interaction regions, and relative positions matching the genetic organization of a given known TA family (Figure 
bioRxiv preprint doi: https://doi.org/10.1101/2021.04.14.439843; this version posted August 13,2021 . The copyright holder for this preprint (which was not certified by peer review) is the author/funder, who has granted bioRxiv a license to display the preprint in perpetuity. It is made available under aCC-BY-NC-ND 4.0 International license.

\section{Tourasse and Darfeuille}

11 and Suppl. Table S1; see Materials and Methods for details). As can be seen in Table 1, using this

2 procedure, we were able to recover RNA regions of the expected family for 83 to $89 \%$ (depending on the family) of the toxin ORFs belonging to five of the seven known families detected by (Fozo et al. 2010) (Suppl. Table S5 therein). The success rate was a bit lower for the TxpA/RatA family (75\%), and particularly low for the Fst/RNAII family (29\%). For most antitoxin asRNAs of the Fst/RNAII family, RNASurface predicts a sequence that folds into a secondary structure different from the typical RNAII structure and IntaRNA does not identify an interaction region with the toxin mRNA at the expected location. Whether this is a prediction issue specific to this family or if this actually represents structural heterogeneity among Fst/RNAII loci requires further study to be determined. In a few additional cases (less than $10 \%$ for each family), a locus could be recovered, but was assigned 11 to a different family. For example, locus TA05747 from Streptococcus thermophilus classified in the Fst/RNAII family (based on peptide features) was identified by our procedure (based on RNA and genetic organization features) as a member of the TxpA/RatA family. This discrepancy could be due to a wrong family assignment by either bioinformatic method or peculiarities in the locus that make it fortuitously look more similar to another family. Important discrepancies occurred for 17 loci (from known families) where our procedure assigned a locus from a Gram-positive bacterium to a family found in Gram-negative organisms (or vice-versa) exhibiting a completely different organization.

18 These were clearly erroneous hits and half of them (e.g., TA07190 from E. coli and TA07194 from Salmonella enterica) were manually corrected and found to match the family predicted by (Fozo et al. 2010). Interestingly, in many of the remaining cases of discrepancy the families show similarities. For instance, locus TA06047 from E. coli classified in the Ldr/Rdl family (based on peptide features) was identified as a member of the Hok/Sok family (based on RNA and genetic organization features).

23 However, $\mathrm{Ldr} / \mathrm{Rd}$ systems exhibit an organization (including a regulatory leader ORF) similar to that of Hok/Sok systems and may be regulated in the same manner (Kawano 2012), thus the RNA-based classification reflects these similarities. Locus TA05436 from Staphylococcus aureus is classified as 
bioRxiv preprint doi: https://doi.org/10.1101/2021.04.14.439843; this version posted August 13, 2021. The copyright holder for this preprint (which was not certified by peer review) is the author/funder, who has granted bioRxiv a license to display the preprint in perpetuity. It is made available under aCC-BY-NC-ND 4.0 International license.

Tourasse and Darfeuille

1 features, but SprA1/SprA1as systems are in fact homologs of Fst/RNAII systems (Weaver et al. 2009;

2 Kwong et al. 2010), and similarly for several loci (e.g., TA05467 from S. aureus) classified as either

3 TxpA/RatA or SprG/SprF (Pinel-Marie et al. 2014). The structural descriptors that we used for

4 RNAMotif searches were mainly based on key determinants of the toxin-encoding mRNA secondary

5 structure, in particular Shine-Dalgarno (SD) and complementary anti-SD sequences, as well as

6 terminator stem-loops in the 3' end, stem-loops in the 5' end, and regions involved in 5'-3' long-

7 distance interactions. Because transcription and translation are coupled in bacteria, cis-encoded regulatory elements prevent premature translation of the toxin mRNA by sequestering the SD sequence, either co- or post-transcriptionally. Depending on the T1TA system, the anti-SD motif is located either at a short distance upstream of the SD sequence, thus creating a sequestering stem-

11 loop, or near the end of the mRNA occluding the SD sequence via a long-distance base-pairing interaction between the 5' and 3' extremities of the mRNA (Masachis and Darfeuille 2018). The overall success of our results demonstrates that taking into account these elements, which are essential for the expression and regulation of T1TA systems, is critical for identifying type I toxin mRNAs.

Information in T1TAdb can be searched by entering one or several keywords via the "Keyword Search" tab. A given keyword may be matched against any field in the database or against a specific field such as toxin or antitoxin name, species, strain, taxonomy, locus ID, or genome accession number. Submitting the search form will return a table listing all loci that match the search criteria. The "Select loci" button in the upper left corner of the table allows to further refine the selection of loci by replicon (chromosome or plasmid), TA family or taxonomy, and to select/deselect

23 all loci. The table indicates the locus identifier (TAnnnnn), TA family, host strain and taxonomy, and reference publication of each locus. For loci that were predicted using structural descriptors of a TA family different from that reported in the literature (i.e., in (Fozo et al. 2010)), the predicted family is indicated in the "putative family" column, and groups of loci from the same genomic region matching 
Tourasse and Darfeuille

1 multiple family characteristics appear under a specific identifier (TAGnnnn; "Overlapping Locus

2 Group", see Materials and Methods for details). The leader ORF is also indicated for loci that have

3 been described in the literature to carry a regulatory leader ORF or for which a leader ORF is

4 annotated (for Hok/Sok and Ldr/Rdl families). The loci table provides explanatory notes that appear

5 when hovering over the red asterisk next to specific items. Clicking on a locus identifier leads to a

6 "Locus Details" page that gives detailed information about the locus. The page is divided into four

7 panels (Figure 2). The "Locus" panel provides genomic information with an interactive full genome

8 map (drawn with CGView; (Stothard and Wishart 2005)) of the host strain, showing the location of

9 all TA loci harbored by the strain, and an embedded interactive genome browser (IGV; (Robinson et

10 al. 2011); https://github.com/igvteam/igv.js/wiki) for viewing the genomic context around the locus.

11 The "mRNA" and "sRNA" panels provide the sequence and secondary structure diagram of the toxin

12 mRNA and antitoxin asRNA, respectively. The location of relevant motifs (promoter -10 box,

13 start/stop codon, SD sequence, leader ORF, mRNA-asRNA interaction region) are annotated on the

14 sequences and /or diagrams. The "Peptide" panel shows the sequence, secondary structure model and

15 hydrophobicity plot of the toxin peptide. The "mRNA", "sRNA", and "Peptide" panels include a

16 "BLAST Sequence" link for launching a sequence homology search (using BLAST+; (Camacho et

17 al. 2009)) of the selected query against every mRNA, asRNA, ORF, peptide, or genome sequence in

18 T1TAdb. The database also allows the user to input or upload one or several query sequences to

19 perform a BLAST search via the "Sequence Search" tab.

The T1TAdb home page contains links to a full list of organisms ("view organism list";

“T1TAdb Organisms” page) and TA families (“view family list”; “T1TAdb Families" page) included

in the database. Selecting a particular organism name or family name will return a table listing all

23 loci that belong to that organism or family. The family table on the "T1TAdb Families" page provides

24 links to the corresponding Rfam entries for antitoxin RNA families that are included in Rfam. In

25 addition, the table is organized to indicate groups of T1TA families that share some degree of

26 homology (in sequence, structure, and/or genetic organization). 
bioRxiv preprint doi: https://doi.org/10.1101/2021.04.14.439843; this version posted August 13, 2021. The copyright holder for this preprint (which was not certified by peer review) is the author/funder, who has granted bioRxiv a license to display the preprint in perpetuity. It is made available under aCC-BY-NC-ND 4.0 International license.

Tourasse and Darfeuille

A notable implementation of T1TAdb is that, in addition to homology searches by BLAST, users can perform multiple sequence alignments (using MAFFT;(Katoh and Standley 2013)) to compare mRNA, asRNA, or peptide sequences. Alignments can be launched via the "Align selected sequences" button on top of the table that is returned after selecting loci by organism or family, or following a keyword search. An embedded interactive alignment viewer (MSAViewer; (Yachdav et al. 2016)) is provided to browse and download the alignments. For RNA sequences, structural

7 information is taken into account in MAFFT to produce a structural alignment (Katoh and Toh 2008), and a consensus 2D structure is predicted (using RNAalifold; (Bernhart et al. 2008)) from the alignment. Furthermore, a covariation analysis is performed (using R-chie; (Lai et al. 2012)) to annotate the alignment with covariation information ((Tourasse and Darfeuille 2020); dedicated links

11 are provided to download the consensus and covariation data). With these programs (and BLAST) T1TAdb aims to provide a selected set of tools (run with most default parameters) for comparative sequence and structure analysis, although users may wish to use custom settings or some of the numerous other tools that exist for doing this kind of analysis. further custom analysis. Once a set of loci has been selected, the corresponding data can be downloaded using the "Download selected loci" menu at the top of the loci table. Users can obtain a spreadsheet file containing the detailed information about the loci (including host organism, genomic coordinates and sequences of the RNA, ORF, peptide, and promoter features) or sequence files in FASTA format. In the "Locus Details" page for a given locus the structure diagrams can be saved in 21 various formats (SVG, PDF, PNG, or GIF).

The list of publications from which sequences, structures, and other information about the

23 T1TA systems have been obtained is given in the "References" page. Links to other resources on TA systems, as well as the various software and tools used to build T1TAdb, are provided in the "Links" page. 
bioRxiv preprint doi: https://doi.org/10.1101/2021.04.14.439843; this version posted August 13, 2021. The copyright holder for this preprint (which was not certified by peer review) is the author/funder, who has granted bioRxiv a license to display the preprint in perpetuity. It is made available under aCC-BY-NC-ND 4.0 International license.

Tourasse and Darfeuille

1 Example of insights gained from the use of T1TAdb

We present below an example illustrating the usefulness and added value provided by

3 T1TAdb. In particular, we would like to highlight the type of sequence and structure analysis that can

4 be done with the database. Examination of the structural diagrams of individual Sok antitoxin

5 asRNAs from the Hok/Sok family suggested that there may be different structural types. This

6 hypothesis could be tested in T1TAdb by performing structural alignments of different subsets of Sok

7 RNAs which revealed two subgroups: one subgroup had a 2D structure conforming to that reported

by (Franch et al. 1997) (Figure 3A), while the other carries an additional stem-loop element at the 5' end (Figure 3B). The covariation analysis that is run on the alignments in T1TAdb confirmed that

this extra element is well supported by covarying positions that reveal compensatory substitutions in

11 a number of sequences. Furthermore, the annotations of the Sok sequences provided in T1TAdb indicated the presence of a -10 box promoter motif (TANNNT, where N means any nucleotide) at an appropriate location upstream of the stem-loop. Although these observations should be verified experimentally, this example shows the potential of T1TAdb to reveal new features in RNA-mediated regulation of T1TA systems by comparative analysis that could not be identified during the study of single T1TA loci.

\section{Conclusions and perspectives}

In this work, we have built the first web database totally dedicated to T1TA systems, named T1TAdb. T1TA systems are widespread in bacteria, including pathogenic species, and are studied for numerous aspects including RNA and protein structure and function, regulation of gene expression and cell physiology. In addition to giving access to the collection of loci that have been reported in

23 the literature, the database brings an added value by the annotation of toxin mRNAs and antitoxin asRNAs of loci that were predicted solely by analysis of the toxin peptide sequence, and by providing tools to compare their sequences and structures. This information, together with a wealth of sequence, 
bioRxiv preprint doi: https://doi.org/10.1101/2021.04.14.439843; this version posted August 13, 2021. The copyright holder for this preprint (which was not certified by peer review) is the author/funder, who has granted bioRxiv a license to display the preprint in perpetuity. It is made available under aCC-BY-NC-ND 4.0 International license.

Tourasse and Darfeuille

1 dedicated to TA systems (such as TADB and TASmania), will certainly serve the scientific

2 community to gain deeper insights of the distribution, evolution, structure, and function of TA

3 systems. This could reveal to be particularly important for the TA systems located in bacterial

4 chromosomes, whose function remains largely unknown. We also believe that the knowledge

5 contained in T1TAdb, and more specifically the RNA structures and loci organization, is a strong

6 asset to help design new tools for identifying new T1TA systems.

In future developments of T1TAdb, we plan to expand the collection of T1TA systems by predicting TA loci in all bacterial genomes available. In addition, the procedure described in this work for the annotation of mRNAs and asRNAs of T1TA systems, which is based on structural features, can be turned into an automatic de novo prediction tool, most likely with additional steps to

11 control the false-positive rate. The RNA data in T1TAdb may also be used to generate alignments 12 and covariance models in order to search genome databases for conserved RNAs, as exemplified in 13 the Rfam database (Kalvari et al. 2021). We also anticipate to incorporate transcriptome (RNA-Seq) 14 data into T1TAdb. As the number of sequenced bacterial transcriptomes is increasing, such 15 information would be valuable to check whether TA loci are expressed and to verify the genomic 16 coordinates of the predicted RNAs. Further improvements to T1TAdb will also include tools for 17 simultaneously visualizing and comparing the genomic context (gene neighborhoods) across multiple 18 strains or for the reconstruction of phylogenetic trees, and will allow users to submit data for inclusion 19 in T1TAdb.

\section{Materials and Methods}


bioRxiv preprint doi: https://doi.org/10.1101/2021.04.14.439843; this version posted August 13, 2021. The copyright holder for this preprint (which was not certified by peer review) is the author/funder, who has granted bioRxiv a license to display the preprint in perpetuity. It is made available under aCC-BY-NC-ND 4.0 International license.

Tourasse and Darfeuille

Sequence, secondary structure, and genomic localization of T1TA loci (including mRNA,

2 asRNA, ORF, and promoter -10 boxes) from the various families were taken from the publications

3 where they were initially discovered and/or characterized (Arnion et al. 2017; Durand et al. 2012;

4 Fozo et al. 2010; Weaver et al. 2009; Maikova et al. 2018; Folli et al. 2017; Kristiansen et al. 2016;

5 Wen and Fozo 2014; Pinel-Marie et al. 2014; Wen et al. 2014; Jahn and Brantl 2013; Weaver 2012;

6 Fozo 2012; Sayed et al. 2012; Han et al. 2010; Sharma et al. 2010; Darfeuille et al. 2007; Pichon and

7 Felden 2005; Kawano et al. 2002; Pedersen and Gerdes 1999; Franch et al. 1997; Masachis and

Darfeuille 2018; Meißner et al. 2016; Peltier et al. 2020; Germain-Amiot et al. 2019; Guo et al. 2014;

Kawano et al. 2007; Andresen et al. 2020). In most cases, reports were on one or few copies of a given TA system, identified or studied in one or a few bacterial strains. Information on TA systems

11 belonging to the AapA/IsoA family identified by bioinformatic analyses and manual curation in $\sim 100$

12 genomes of Helicobacter and Campylobacter were taken from (Arnion et al. 2017). (Sharma et al.

13 2010) reported members of the AapB/IsoB, AapC/IsoC, and AapD/IsoD families in six Helicobacter

14 strains. For the sake of consistency and completeness, we located the homologues of these loci in all

15 other Helicobacter genomes screened by (Arnion et al. 2017) through sequence homology searches

16 (using BLAST+2.2.31; (Camacho et al. 2009)) and multiple sequence alignment. (Kristiansen et al.

17 2016) identified mRNAs and ORFs belonging to the DinQ/AgrB family in 15 Gram-negative bacteria

18 and we devised a procedure to predict the corresponding asRNAs (see below). The majority of the

19 data in T1TAdb are based on the genome-wide bioinformatic searches by (Fozo et al. 2010) who

20 identified sequences of ORFs coding for type I toxin peptides of known and novel families in

21 hundreds of bacterial strains. For toxins belonging to known TA families, we performed 22 computational analyses to locate the coordinates of the toxin mRNA and antitoxin asRNA in order to 23 identify the complete TA locus corresponding to each reported toxin ORF. 
bioRxiv preprint doi: https://doi.org/10.1101/2021.04.14.439843; this version posted August 13, 2021. The copyright holder for this preprint (which was not certified by peer review) is the author/funder, who has granted bioRxiv a license to display the preprint in perpetuity. It is made available under aCC-BY-NC-ND 4.0 International license.

Tourasse and Darfeuille

Identification of mRNAs and asRNAs was based on the characteristics of known examples.

2 The prediction pipeline is summarized in Fig. 1. Genomic locations of toxin mRNAs were determined using RNAMotif 3.1.1 (Macke et al. 2001). RNAMotif takes as input a descriptor file that contains parameters describing the various elements that make up the secondary structure of a particular RNA (helices, loops, etc. and their respective lengths). Using this descriptor RNAMotif scans genome sequences to find regions that can adopt (i.e., can be folded into) the specified structure. RNAMotif descriptors for mRNAs belonging to 16 known T1TA families were written based on sequences and secondary structures reported in the literature cited above. We did not include every structural element in the descriptors, but rather focused on key determinants such as SD and anti-SD sequences (that sequester the SD motif), location of the ORF within the mRNA, stem-loops in the 5' end or terminator stem-loops in the 3' end, and regions implicated in 5'-3' long-distance interactions (textual summary of RNAMotif parameters given in Suppl. Table S1). The remaining parts of the structure were specified as undefined regions. To avoid descriptors being too specific to a given mRNA instance, lengths and distances between the various elements were usually not set to a defined value but to a min./max. value or a relatively broad range of values. All genomes surveyed by (Fozo et al. 2010) (genome sequences downloaded from NCBI RefSeq; (Haft et al. 2018)) were scanned by RNAMotif with descriptors of all 16 TA families. Hits that spanned the coordinates of the ORFs reported by Fozo et al. on the same DNA strand were extracted (by means of the "intersectbed" utility from the BEDTools 2.24.0 package (Quinlan and Hall 2010)). Among those, hits that contained ORFs that were in-frame with the ORFs of Fozo et al. (ORFs may not always be identical and could differ slightly in length in some cases depending on the start codon used) and whose ORF and total mRNA length matched the typical range of ORF and mRNA length for a given family were retrieved, whether or not the family matched that reported by Fozo and coworkers. 
Tourasse and Darfeuille

1 options “--winmin 50 --winmax 300 -z -2 -d 500”) to identify structured segments of length 50-300

2 nt that have a z-score lower than -2 (corresponding to a false-positive rate of 5\%, (Soldatov et al.

3 2014)). For a given TA family, RNASurface segments whose length corresponded to the typical

4 asRNA length for that family (+/- 20\%) were retrieved.

Putative promoter -10 boxes were predicted by searching (by means of the PERL module

Regexp::Exhaustive) for the presence of the sequence motif TANNNT (where $\mathrm{N}$ means any

nucleotide) in a window covering the region -20 to -6 upstream of the identified mRNAs and asRNAs.

In case where multiple motifs were present the 3'-most (i.e., the closest to the RNA start) was selected.

In order to find the pair of mRNA and asRNA corresponding to the same TA locus, RNAMotif and RNASurface results were intersected (using "intersectbed" from BEDTools) based on the defined genetic organization of the various T1TA families. In the ShoB/OhsC, TisB/IstR1, Zor/Orz, and DinQ/AgrB families, found in Gram-negative bacteria, the asRNA is located 5 ' to the mRNA and does not overlap it, whereas in the Fst/RNAII, TxpA/RatA, YonT/as-YonT, SprA1/SprA1as, SprG/SprF, and BsrE-G-H/as-BsrE-G-H families, all found in Gram-positive bacteria, the asRNA is located on the 3' side of the mRNA and partially overlaps it (overlaps also the ORF except in the Fst/RNAII family); the asRNA is fully overlapped by the mRNA in the AapA/IsoA, Ibs/Sib, Hok/Sok, and Ldr/Rdl families from Gram-negative organisms, but overlaps the ORF only in the AapA/IsoA and Ibs/Sib families (spans the entire ORF in Ibs/Sib), whereas it is located 5' of the ORF in the Hok/Sok and Ldr/Rdl families ((Wen and Fozo 2014; Arnion et al. 2017; Pinel-Marie et al. 2014; Durand et al. 2012; Sayed et al. 2012); Suppl. Table S1). For families where the two RNAs do not overlap, a max. distance of 300 nt between the RNAs was allowed (except for the DinQ/AgrB

23 family, see below), and for families where the two RNAs do overlap, min. and max. limits were set for the length of the overlap region based on known examples (Suppl. Table S1). In T1TA systems the mRNA and asRNA share a complementary region of interaction. In families with overlapping 
bioRxiv preprint doi: https://doi.org/10.1101/2021.04.14.439843; this version posted August 13, 2021. The copyright holder for this preprint (which was not certified by peer review) is the author/funder, who has granted bioRxiv a license to display the preprint in perpetuity. It is made available under aCC-BY-NC-ND 4.0 International license.

Tourasse and Darfeuille

1 SprA1/SprA1as families interaction occurs outside the overlap sequence (Weaver et al. 2009; Sayed

2 et al. 2012). The software IntaRNA 3.1.0.2 (Mann et al. 2017) was used to find mRNA-asRNA pairs

3 that share a complementary region at the expected location for these two families and to identify

4 regions of interaction for families with non-overlapping RNAs (the interaction region was set to be

5 at least $15 \mathrm{nt}$ long). A specific processing was carried out for the DinQ/AgrB family because in some

6 bacterial strains the locus includes an AgrA ncRNA gene that is homologous to the AgrB asRNA and

7 that can be located in-between DinQ and AgrB. In Escherichia coli K-12 substr. MG1655 the sequence of the interaction region in AgrA contains a number of mismatches and it has been shown that AgrA does not bind the DinQ mRNA and that only AgrB, which shares a region almost fully complementary to DinQ, acts as an antitoxin (Kristiansen et al. 2016). Therefore, to accommodate

11 for the possible presence of the AgrA and AgrB paralogs, the max. distance between the mRNA and asRNA was extended from 300 to $500 \mathrm{nt}$. In cases where two asRNAs were predicted in this region by RNASurface and for both of them a possible sequence of interaction ( $\geq 15 \mathrm{nt}$ ) with the mRNA was identified by IntaRNA, we selected the one for which the interaction was predicted to be the most stable (i.e., had the lowest free energy as computed by IntaRNA). The same procedure was followed to predict the asRNAs corresponding to the DinQ-like loci reported in (Kristiansen et al. 2016) where only mRNAs and ORFs were annotated.

Following the characteristics described above, all pairs of mRNAs and asRNAs that were in the correct orientation and distance and that shared a complementary interaction region were identified for each family. This set of pairs was then intersected with the set of mRNAs that were found to encode ORFs corresponding to those reported by (Fozo et al. 2010), to obtain the pairs that include a known ORF (Fig. 1). For a given locus, there were usually several mRNAs and asRNAs 23 matching these criteria because we used a relatively broad range of values for the parameters describing the length, structure, and organization of the RNAs. Due to the flexibility in the RNAMotif structural descriptors multiple overlapping mRNAs spanning the same ORF were always found, differing by their lengths and a few bases in their start/end coordinates. Among those, the one for 
bioRxiv preprint doi: https://doi.org/10.1101/2021.04.14.439843; this version posted August 13, 2021. The copyright holder for this preprint (which was not certified by peer review) is the author/funder, who has granted bioRxiv a license to display the preprint in perpetuity. It is made available under aCC-BY-NC-ND 4.0 International license.

Tourasse and Darfeuille

1 which a promoter -10 box could be predicted was selected as the mRNA for the given locus. If a

2 promoter was predicted for multiple mRNAs, or if no promoter was found for any of the mRNAs, then RNA sequences were folded using MFOLD 3.6 (Zuker 1989, 2003) and the minimum free energy (MFE) of the most stable structure of each RNA was normalized by sequence length (adjusted MFE; AMFE) to compare the stability among RNAs. The mRNA that had the smallest AMFE was taken as the mRNA for the locus. The use of AMFE was warranted by the fact that mRNA lengths of the different T1TA families are in the range 200-400 nt where AMFE is almost length-independent (Trotta 2014). For some loci, there were also several possible asRNAs matching the TA family characteristics as RNASurface often predicts multiple RNA segments of different lengths overlapping the same genomic region. Among those, the one for which a promoter -10 box was predicted was selected as the asRNA for the locus. If a promoter was predicted for multiple asRNAs, or if no promoter was found for any of the asRNAs, then the one with the lowest RNASurface z-score was chosen as the putative asRNA for the given locus. Z-score was used here as normalized folding stability measure because asRNA lengths are in the range 60-200 nt where AMFE is length-dependent and thus cannot be reliably used to compare stabilities among RNAs (Trotta 2014).

To verify that the correct asRNA was associated with a given mRNA, an alignment of the antitoxin sequences was made for each family to check the homology and completeness of the sequences. The alignment included only the RNAs whose family corresponded to the family of the ORF in (Fozo et al. 2010), in which case one should expect these sequences to be homologous to each other. Incomplete sequences or sequences whose coordinates were shifted relative to the others were manually corrected. No alignment was done for the mRNAs because they are constrained by the location of the ORFs and thus are normally homologous. found, that particular ORF was not included in T1TAdb. However, in cases where no mRNA-asRNA pair corresponding to the same family as that assigned to the ORF in (Fozo et al. 2010) could be identified but the ORF was included in an RNA pair of a different family, the locus was retained and 
bioRxiv preprint doi: https://doi.org/10.1101/2021.04.14.439843; this version posted August 13, 2021. The copyright holder for this preprint (which was not certified by peer review) is the author/funder, who has granted bioRxiv a license to display the preprint in perpetuity. It is made available under aCC-BY-NC-ND 4.0 International license.

Tourasse and Darfeuille

1 a "putative_family" flag was set to indicate that it matched an alternative family. This flag was also

2 set when ORFs from unknown or novel families were part of loci corresponding to known families.

3 If RNA pairs of multiple TA families spanned the same ORF, only the one matching the family of

4 the ORF was retained. If there were no such pair, then alternative loci were filtered according to the

5 type of organism in which the ORF was encoded, i.e., for a Gram-negative bacterium only the RNA

6 pairs from families found in Gram-negative bacteria were retained, and similarly for Gram-positive

7 organisms. If there were no such pairs, then all alternative mRNA-asRNA pairs covering the ORF

8 were retained. The multiple loci spanning a given ORF were organized into an "Overlapping Locus

9 Group", which represents a group of loci that have been identified using characteristics of different

10 TA families and that overlap the same genomic region, but we could not determine which one is the

11 real locus in this region.

Database implementation

T1TAdb is implemented as a relational database in PostgreSQL 10.13

15 (https://www.postgresql.org/). The database schema was designed following the five rules of 16 normalization (http://www.barrywise.com/2008/01/database-normalization-and-design-techniques/)

17 to avoid data redundancy and inconsistent dependency among tables. The graphical web interface

18 was developed using the PERL Catalyst framework (http://www.catalystframework.org/) to control

19 and manage connections and SQL requests to the database. Graphical design of the web pages was

20 done in dynamic and responsive HTML, JavaScript, and Cascading Style Sheets (CSS)

21 (https://www.w3schools.com/), along with the PERL Template Toolkit 2.26 templating system

22 (http://www.template-toolkit.org/). The T1TAdb website is run via the Apache HTTP 2.4.6 server

23 (https://httpd.apache.org/) under the Linux CentOS 7.8 operating system. Secondary structures of

24 RNA were predicted using MFOLD 3.6 (Zuker 2003, 1989) and annotated diagrams highlighting the

25 location of specific motifs (start/stop codon, SD sequence, interaction region)were generated with

26 VARNA 3.93 (Darty et al. 2009). Secondary structures of toxin peptides were predicted using 
bioRxiv preprint doi: https://doi.org/10.1101/2021.04.14.439843; this version posted August 13, 2021. The copyright holder for this preprint (which was not certified by peer review) is the author/funder, who has granted bioRxiv a license to display the preprint in perpetuity. It is made available under aCC-BY-NC-ND 4.0 International license.

Tourasse and Darfeuille

1 PSIPRED 4.02 (McGuffin et al. 2000) run with PSI-BLAST 2.2.26 against the UniRef90 protein

2 sequence database (https://www.uniprot.org/help/uniref) and drawn with POLYVIEW-2D (Porollo

3 et al. 2004). Hydrophobicity plots were computed with ProtScale (Gasteiger et al. 2005). Interactive

4 genomic maps in SVG format showing the localizations of TA loci were drawn using CGView

5 (Stothard and Wishart 2005). The embeddable JavaScript/CSS version of the IGV browser

6 ((Robinson et al. 2011); https://github.com/igvteam/igv.js/wiki) was used to provide an interactive

7 visualization of the genomic context flanking TA loci, and SVG images of the genomic context were

8 generated by means of the Gviz package

9 (https://bioconductor.org/packages/release/bioc/html/Gviz.html) in R 3.5.3 ((R Development Core

10 Team 2019); https://www.r-project.org/). Sequence similarity searches in T1TAdb are done with

11 BLAST+2.2.31 (Camacho et al. 2009) and multiple sequence alignments are computed by MAFFT

127.407 (Katoh and Standley 2013). For peptide sequences MAFFT is run with the method "mafft-

13 linsi" and the option "--localpair", whereas for RNA sequences MAFFT is run with the method

14 "mafft-xinsi" and the option "--scarnapair" to incorporate structure information and produce a

15 structural alignment (Katoh and Toh 2008). Alignments are visualized using the embeddable

16 MSAViewer (Yachdav et al. 2016), which is part of the BioJS JavaScript tools (Yachdav et al. 2015).

17 In addition, for RNA alignments, a consensus structure is predicted by means of RNAalifold from

18 the ViennaRNA 2.1.9 package (Lorenz et al. 2011; Bernhart et al. 2008) and a covariation analysis is

19 conducted using R-chie (Lai et al. 2012). Other bioinformatic software such as EMBOSS 6.6.0 (Rice

20 et al. 2000), BioPERL (Stajich et al. 2002), and FASTX-Toolkit 0.0.14

21 (http://hannonlab.cshl.edu/fastx_toolkit/) were also employed to generate and/or process the data 22 included in T1TAdb.

\section{Acknowledgements}

This work was supported by Institut National de la Santé et de la Recherche Médicale 
bioRxiv preprint doi: https://doi.org/10.1101/2021.04.14.439843; this version posted August 13, 2021. The copyright holder for this preprint (which was not certified by peer review) is the author/funder, who has granted bioRxiv a license to display the preprint in perpetuity. It is made available under aCC-BY-NC-ND 4.0 International license.

Tourasse and Darfeuille

1 University, and Agence Nationale de la Recherche [ANR-12-BSV5-0025-Bactox1, ANR-12-BSV6-

2 0007-asSUPYCO]. The web server hosting T1TAdb is provided by the ODS Web Hosting service of

3 CNRS. We thank Dr. Stéphane Thore and Dr. Sébastien Fribourg for providing additional computing

4 power. Finally, we thank all present and past members of the Darfeuille laboratory for fruitful

5 discussions on this project and Anthony Bugaut, Isabelle Iost, Anaïs Le Rhun, Simon Bonabal, and

6 Olga Soutourina for critical comments on the manuscript.

\section{References}

Akarsu H, Bordes P, Mansour M, Bigot DJ, Genevaux P, Falquet L. 2019. TASmania: A bacterial toxin-antitoxin systems database. PLoS Comput Biol 15: e1006946.

Andresen L, Martínez-Burgo Y, Zangelin JN, Rizvanovic A, Holmqvist E. 2020. The small toxic salmonella protein timp targets the cytoplasmic membrane and is repressed by the small rna timr. MBio 11: e01659-20.

Arnion H, Korkut DN, Gelo SM, Chabas S, Reignier J, Iost I, Darfeuille F. 2017. Mechanistic

Barbosa LCB, Garrido SS, Marchetto R. 2015. BtoxDB: A comprehensive database of protein structural data on toxin-antitoxin systems. Comput Biol Med 58: 146-153.

Bernhart SH, Hofacker IL, Will S, Gruber AR, Stadler PF. 2008. RNAalifold: Improved consensus structure prediction for RNA alignments. BMC Bioinformatics 9: 474.

Brielle R, Pinel-Marie M-L, Felden B. 2016. Linking bacterial type I toxins with their actions. Curr Opin Microbiol 30: 114-121.

Camacho C, Coulouris G, Avagyan V, Ma N, Papadopoulos J, Bealer K, Madden TL. 2009. BLAST+: Architecture and applications. BMC Bioinformatics 10: 1-9. 
bioRxiv preprint doi: https://doi.org/10.1101/2021.04.14.439843; this version posted August 13, 2021. The copyright holder for this preprint (which was not certified by peer review) is the author/funder, who has granted bioRxiv a license to display the preprint in perpetuity. It is made available under aCC-BY-NC-ND 4.0 International license.

Tourasse and Darfeuille

1 Darty K, Denise A, Ponty Y. 2009. VARNA: Interactive drawing and editing of the RNA secondary structure. Bioinformatics 25: 1974-1975.

Durand S, Jahn N, Condon C, Brantl S. 2012. Type I toxin-antitoxin systems in Bacillus subtilis. RNA Biol 9: 1491-1497.

Folli C, Levante A, Percudani R, Amidani D, Bottazzi S, Ferrari A, Rivetti C, Neviani E, Lazzi C. 2017. Toward the identification of a type i toxin-antitoxin system in the plasmid DNA of dairy Lactobacillus rhamnosus. Sci Rep 7: 1-13.

Fozo EM. 2012. New type I toxin-antitoxin families from “wild” and laboratory strains of E. coli: Ibs-Sib, ShoB-OhsC and Zor-Orz. RNA Biol 9: 1504-1512.

Fozo EM, Makarova KS, Shabalina SA, Yutin N, Koonin E V., Storz G. 2010. Abundance of type I toxin-antitoxin systems in bacteria: Searches for new candidates and discovery of novel families. Nucleic Acids Res 38: 3743-3759.

Franch T, Gultyaev AP, Gerdes K. 1997. Programmed cell death by hok/sok of plasmid R1: processing at the hok mRNA 3'-end triggers structural rearrangements that allow translation and antisense RNA binding. J Mol Biol 273: 38-51.

Gasteiger E, Hoogland C, Gattiker A, Duvaud S, Wilkins MR, Appel RD, Bairoch A. 2005. The Proteomics Protocols Handbook. 571-608.

Gerdes K, Rasmussen PB, Molin S. 1986. Unique type of plasmid maintenance function: postsegregational killing of plasmid-free cells. Proc Natl Acad Sci 83: 3116-3120.

Germain-Amiot N, Augagneur Y, Camberlein E, Nicolas I, Lecureur V, Rouillon A, Felden B. 2019. A novel Staphylococcus aureus cis-trans type I toxin-antitoxin module with dual effects on bacteria and host cells. Nucleic Acids Res 47: 1759-1773.

Greenfield TJ, Ehli E, Kirshenmann T, Franch T, Gerdes K, Weaver KE. 2000. The antisense RNA of the par locus of $\mathrm{pAD} 1$ regulates the expression of a 33-amino-acid toxic peptide by an unusual mechanism. Mol Microbiol 37: 652-660.

Guo Y, Quiroga C, Chen Q, McAnulty MJ, Benedik MJ, Wood TK, Wang X. 2014. RalR (a 
bioRxiv preprint doi: https://doi.org/10.1101/2021.04.14.439843; this version posted August 13, 2021. The copyright holder for this preprint (which was not certified by peer review) is the author/funder, who has granted bioRxiv a license to display the preprint in perpetuity. It is made available under aCC-BY-NC-ND 4.0 International license.

Tourasse and Darfeuille

DNase) and RalA (a small RNA) form a type I toxin-antitoxin system in Escherichia coli. Nucleic Acids Res 42: 6448-6462.

Haft DH, DiCuccio M, Badretdin A, Brover V, Chetvernin V, O’Neill K, Li W, Chitsaz F, Derbyshire MK, Gonzales NR, et al. 2018. RefSeq: An update on prokaryotic genome annotation and curation. Nucleic Acids Res 46: D851-D860.

Han K, Kim KS, Bak G, Park H, Lee Y. 2010. Recognition and discrimination of target mRNAs by Sib RNAs, a cis-encoded sRNA family. Nucleic Acids Res 38: 5851-5866.

Harms A, Brodersen DE, Mitarai N, Gerdes K. 2018. Toxins, Targets, and Triggers: An Overview of Toxin-Antitoxin Biology. Mol Cell 70: 768-784.

Jahn N, Brantl S. 2013. One antitoxin-two functions: SR4 controls toxin mRNA decay and translation. Nucleic Acids Res 41: 9870-9880.

Kalvari I, Nawrocki EP, Ontiveros-Palacios N, Argasinska J, Lamkiewicz K, Marz M, GriffithsJones S, Toffano-Nioche C, Gautheret D, Weinberg Z, et al. 2021. Rfam 14: expanded coverage of metagenomic, viral and microRNA families. Nucleic Acids Res 49: D192-D200.

Katoh K, Standley DM. 2013. MAFFT multiple sequence alignment software version 7: Improvements in performance and usability. Mol Biol Evol 30: 772-780.

Katoh K, Toh H. 2008. Improved accuracy of multiple ncRNA alignment by incorporating structural information into a MAFFT-based framework. BMC Bioinformatics 9: 212.

Kawano M. 2012. RNA Biology Divergently overlapping cis-encoded antisense RNA regulating toxin-antitoxin systems from E. coli hok/sok, ldr/rdl, symE/symR. 9: 1520-1527.

Kawano M, Aravind L, Storz G. 2007. An antisense RNA controls synthesis of an SOS-induced toxin evolved from an antitoxin. Mol Microbiol 64: 738-754.

Kawano M, Oshima T, Kasai H, Mori H. 2002. Molecular characterization of long direct repeat (LDR) sequences expressing a stable mRNA encoding for a 35-amino-acid cell-killing peptide and a cis-encoded small antisense RNA in Escherichia coli. Mol Microbiol 45: 333-349.

Kristiansen KI, Weel-Sneve R, Booth JA, Bjørås M. 2016. Mutually exclusive RNA secondary 
bioRxiv preprint doi: https://doi.org/10.1101/2021.04.14.439843; this version posted August 13, 2021. The copyright holder for this preprint (which was not certified by peer review) is the author/funder, who has granted bioRxiv a license to display the preprint in perpetuity. It is made available under aCC-BY-NC-ND 4.0 International license.

Tourasse and Darfeuille

structures regulate translation initiation of DinQ in Escherichia coli. RNA 22: 1739-1749.

Kwong SM, Jensen SO, Firth N. 2010. Prevalence of Fst-like toxin-antitoxin systems. Microbiology 156: $975-977$.

Lai D, Proctor JR, Zhu JYA, Meyer IM. 2012. R-CHIE: A web server and R package for visualizing RNA secondary structures. Nucleic Acids Res 40: e95.

Lorenz R, Bernhart SH, Höner zu Siederdissen C, Tafer H, Flamm C, Stadler PF, Hofacker IL. 2011. ViennaRNA Package 2.0. Algorithms Mol Biol 6: 26.

Macke TJ, Ecker DJ, Gutell RR, Gautheret D, Case DA, Sampath R. 2001. RNAMotif, an RNA secondary structure definition and search algorithm. Nucleic Acids Res 29: 4724-4735.

Maikova A, Peltier J, Boudry P, Hajnsdorf E, Kint N, Monot M, Poquet I, Martin-Verstraete I, Dupuy B, Soutourina O. 2018. Discovery of new type I toxin-antitoxin systems adjacent to CRISPR arrays in Clostridium difficile. Nucleic Acids Res 46: 4733-4751.

Mann M, Wright PR, Backofen R. 2017. IntaRNA 2.0: Enhanced and customizable prediction of RNA-RNA interactions. Nucleic Acids Res 45: W435-W439.

Masachis S, Darfeuille F. 2018. Type I Toxin-Antitoxin Systems: Regulating Toxin Expression via Shine-Dalgarno Sequence Sequestration and Small RNA Binding. Regul with RNA Bact Archaea 173-190.

McGuffin LJ, Bryson K, Jones DT. 2000. The PSIPRED protein structure prediction server. Bioinformatics 16: 404-405.

Meißner C, Jahn N, Brantl S. 2016. In Vitro Characterization of the Type I Toxin-Antitoxin System bsrE/SR5 from Bacillus subtilis. J Biol Chem 291: 560-71.

Page R, Peti W. 2016. Toxin-antitoxin systems in bacterial growth arrest and persistence. Nat Chem Biol 12: 208-214.

Pedersen K, Gerdes K. 1999. Multiple hok genes on the chromosome of Escherichia coli. Mol Microbiol 32: 1090-1102.

Peltier J, Hamiot A, Garneau JR, Boudry P, Maikova A, Hajnsdorf E, Fortier LC, Dupuy B, 
bioRxiv preprint doi: https://doi.org/10.1101/2021.04.14.439843; this version posted August 13, 2021. The copyright holder for this preprint (which was not certified by peer review) is the author/funder, who has granted bioRxiv a license to display the preprint in perpetuity. It is made available under aCC-BY-NC-ND 4.0 International license.

Tourasse and Darfeuille

Soutourina O. 2020. Type I toxin-antitoxin systems contribute to mobile genetic elements maintenance in Clostridioides difficile and can be used as a counter-selectable marker for chromosomal manipulation. Commun Biol 3: 718.

Pichon C, Felden B. 2005. Small RNA genes expressed from Staphylococcus aureus genomic and pathogenicity islands with specific expression among pathogenic strains. Proc Natl Acad Sci U S A 102: 14249-14254.

Pinel-Marie M-L, Brielle R, Felden B. 2014. Dual Toxic-Peptide-Coding Staphylococcus aureus RNA under Antisense Regulation Targets Host Cells and Bacterial Rivals Unequally. Cell Rep 7: $424-435$.

Porollo AA, Adamczak R, Meller J. 2004. POLYVIEW: A flexible visualization tool for structural and functional annotations of proteins. Bioinformatics 20: 2460-2462.

Quinlan AR, Hall IM. 2010. BEDTools: A flexible suite of utilities for comparing genomic features. Bioinformatics 26: 841-842.

R Development Core Team. 2019. R: A language and environment for statistical computing. $R$ Found Stat Comput. https://www.r-project.org/.

Rice P, Longden I, Bleasby A. 2000. EMBOSS: the European Molecular Biology Open Software Suite. Trends Genet 16: 276-7.

Robinson JT, Thorvaldsdóttir H, Winckler W, Guttman M, Lander ES, Getz G, Mesirov JP. 2011. Integrative genomics viewer. Nat Biotechnol 29: 24-6.

Sayed N, Jousselin A, Felden B. 2012. A cis-antisense RNA acts in trans in Staphylococcus aureus to control translation of a human cytolytic peptide. Nat Struct Mol Biol 19: 105-113.

Sevin EW, Barloy-Hubler F. 2007. RASTA-Bacteria: A web-based tool for identifying toxinantitoxin loci in prokaryotes. Genome Biol $\mathbf{8}$.

Sharma CM, Hoffmann S, Darfeuille F, Reignier J, Findeiß S, Sittka A, Chabas S, Reiche K, Hackermüller J, Reinhardt R, et al. 2010. The primary transcriptome of the major human pathogen Helicobacter pylori. Nature 464: 250-255. 
bioRxiv preprint doi: https://doi.org/10.1101/2021.04.14.439843; this version posted August 13, 2021. The copyright holder for this preprint (which was not certified by peer review) is the author/funder, who has granted bioRxiv a license to display the preprint in perpetuity. It is made available under aCC-BY-NC-ND 4.0 International license.

Tourasse and Darfeuille

1 Soldatov RA, Vinogradova S V., Mironov AA. 2014. RNASurface: Fast and accurate detection of locally optimal potentially structured RNA segments. Bioinformatics 30: 457-463.

Stajich JE, Block D, Boulez K, Brenner SE, Chervitz SA, Dagdigian C, Fuellen G, Gilbert JGR, Korf I, Lapp H, et al. 2002. The Bioperl toolkit: Perl modules for the life sciences. Genome Res 12: 1611-1618.

Stothard P, Wishart DS. 2005. Circular genome visualization and exploration using CGView. Bioinformatics 21: 537-539.

Tourasse NJ, Darfeuille F. 2020. Structural Alignment and Covariation Analysis of RNA Sequences. Bio-Protocol 10: e3511.

Trotta E. 2014. On the normalization of the minimum free energy of RNAs by sequence length. PLoS One 9.

Wang X, Yao J, Sun YC, Wood TK. 2021. Type VII Toxin/Antitoxin Classification System for Antitoxins that Enzymatically Neutralize Toxins. Trends Microbiol 29: 388-393.

Weaver KE. 2012. The par toxin-antitoxin system from Enterococcus faecalis plasmid pAD1 and its chromosomal homologs. RNA Biol 9: 1498-1503.

Weaver KE, Reddy SG, Brinkman CL, Patel S, Bayles KW, Endres JL. 2009. Identification and characterization of a family of toxin-antitoxin systems related to the Enterococcus faecalis plasmid pAD1 par addiction module. Microbiology 155: 2930-2940.

Wen J, Fozo EM. 2014. sRNA antitoxins: More than one way to repress a toxin. Toxins (Basel) 6: 2310-2335.

Wen J, Won D, Fozo EM. 2014. The ZorO-OrzO type I toxin-Antitoxin locus: Repression by the OrzO antitoxin. Nucleic Acids Res 42: 1930-1946.

Xie Y, Wei Y, Shen Y, Li X, Zhou H, Tai C, Deng Z, Ou HY. 2018. TADB 2.0: An updated database of bacterial type II toxin-antitoxin loci. Nucleic Acids Res 46: D749-D753.

Yachdav G, Goldberg T, Wilzbach S, Dao D, Shih I, Choudhary S, Crouch S, Franz M, García A, García LJ, et al. 2015. Anatomy of BioJS, an open source community for the life sciences. 
bioRxiv preprint doi: https://doi.org/10.1101/2021.04.14.439843; this version posted August 13, 2021. The copyright holder for this preprint (which was not certified by peer review) is the author/funder, who has granted bioRxiv a license to display the preprint in perpetuity. It is made available under aCC-BY-NC-ND 4.0 International license.

Tourasse and Darfeuille

Elife 4: 1-7.

2 Yachdav G, Wilzbach S, Rauscher B, Sheridan R, Sillitoe I, Procter J, Lewis SE, Rost B, Goldberg T. 2016. MSAViewer: Interactive JavaScript visualization of multiple sequence alignments. Bioinformatics 32: 3501-3503.

5 Zuker M. 2003. Mfold web server for nucleic acid folding and hybridization prediction. Nucleic Acids Res 31: 3406-3415.

7 Zuker M. 1989. On finding all suboptimal foldings of an RNA molecule. Science 244: 48-52.

8 
bioRxiv preprint doi: https://doi.org/10.1101/2021.04.14.439843; this version posted August 13, 2021. The copyright holder for this preprint (which was not certified by peer review) is the author/funder, who has granted bioRxiv a license to display the preprint in perpetuity. It is made available under aCC-BY-NC-ND 4.0 International license.

Tourasse and Darfeuille

\section{Tables}

2 Table 1. Identification by RNAMotif and RNASurface of toxin-antitoxin mRNA-asRNA pairs

3 corresponding to toxin ORF loci predicted by (Fozo et al. 2010).

4

\begin{tabular}{|l|l|l|l|}
\hline TA family & $\begin{array}{l}\text { \# of ORFs predicted } \\
\text { by (Fozo et al. 2010) }\end{array}$ & $\begin{array}{l}\text { \# of mRNA-asRNA pairs identified } \\
\text { at the corresponding loci and with } \\
\text { the corresponding family }\end{array}$ & $\begin{array}{l}\text { at } \text { of } \text { the corresponding loci but with } \\
\text { an alternative family }\end{array}$ \\
\hline Ldr/Rdl, & $298(162,136)$ & $175(136,39)$ & $16(5,11)$ \\
\hline Fst/RNAII & & & \\
\hline Ibs/Sib & 210 & 160 & 0 \\
\hline ShoB/OhsC & 31 & 182 & 3 \\
\hline TisB/IstR1 & 45 & 26 & 0 \\
\hline TxpA/RatA & 122 & 39 & 12 \\
\hline
\end{tabular}

6 aIn (Fozo et al. 2010) members of the Ldr/Rdl and Fst/RNAII families were classified together due

7 to remote similarity between toxin protein sequences of the two families (numbers in parentheses

8 correspond to counts that would be obtained if systems from Gram-negative and Gram-positive

9 organisms are assigned to the Ldr/Rdl and Fst/RNAII family, respectively). 
bioRxiv preprint doi: https://doi.org/10.1101/2021.04.14.439843; this version posted August 13, 2021. The copyright holder for this preprint (which was not certified by peer review) is the author/funder, who has granted bioRxiv a license to display the preprint in perpetuity. It is made available under aCC-BY-NC-ND 4.0 International license.

Tourasse and Darfeuille

\section{$1 \quad$ Figure legends}

2 Fig. 1. Automatic annotation of mRNAs and asRNAs of known type I TA systems.

4 Fig. 2. Screenshot of a "Locus Details" page in T1TAdb showing the various panels with sequence, structure, and genomic information.

7 Fig. 3. Structural alignments of two subgroups of Sok asRNAs from various Gram-negative bacteria.

8 The structure of the subgroup shown in panel A matches that reported by (Franch et al. 1997) while

9 the subgroup shown in panel B exhibits an additional stem-loop element at the 5' end. Alignments

10 were computed using MAFFT (and slightly corrected manually) and annotated with covariation

11 information using R-chie. A region of $30 \mathrm{nt}$ upstream of the RNAs was added that includes matches

12 to the -10 promoter box motif (UANNNU, where $\mathrm{N}$ means any nucleotide) highlighted in dark 13 orange. 


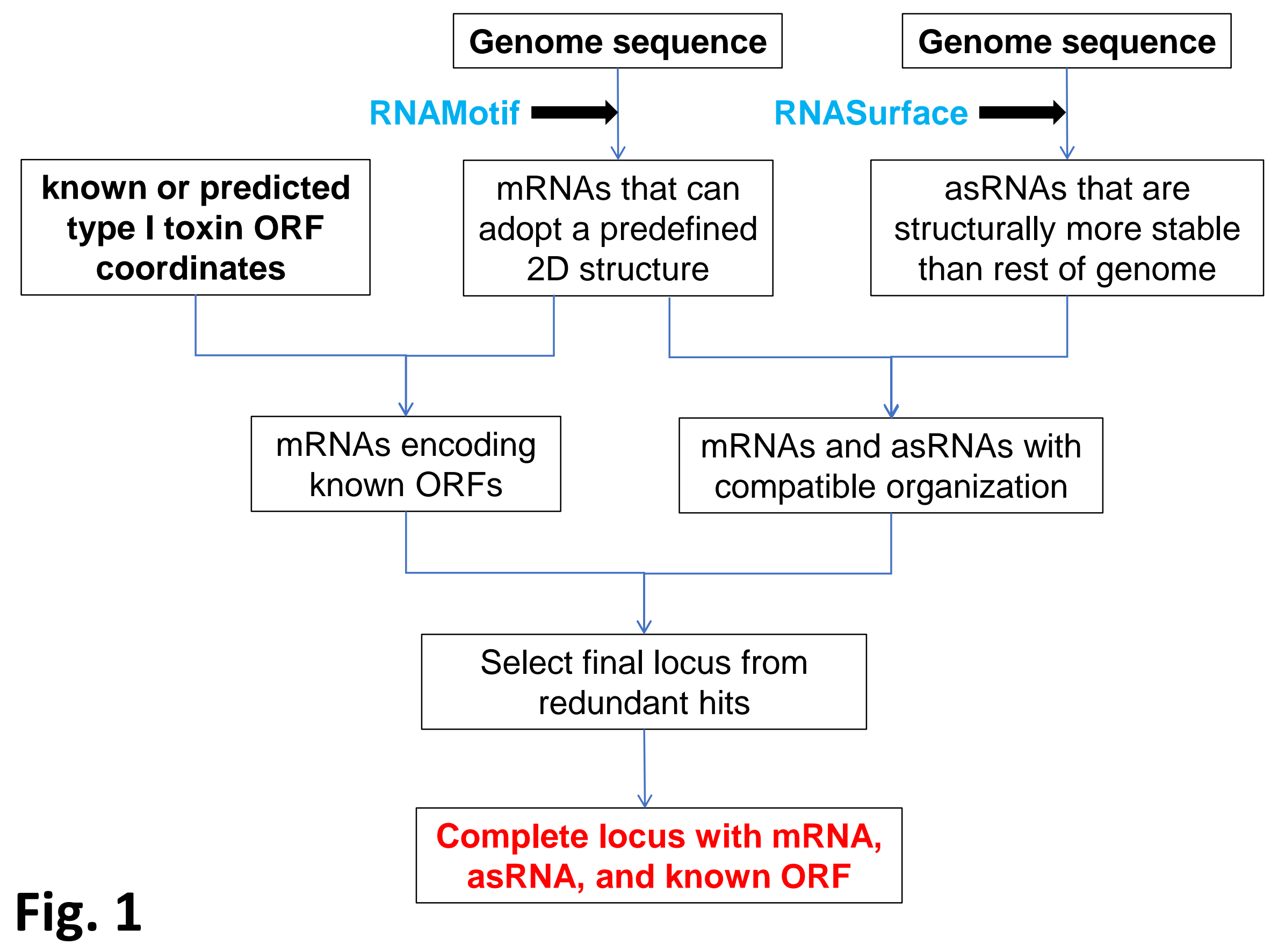


T1TAdb Locus Details

\section{Locis TA}

Locus

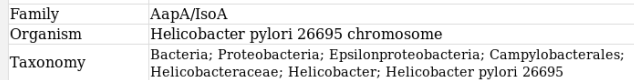

Helicobacteracece
Genomic location chromosome
Genomic

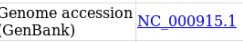

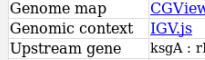

Toxin mRNA

Name AapA3

Locus_tag

Genomic
coordinates $\quad$ 1503082-1503303 (strand + )

Length $222 \mathrm{nt}$

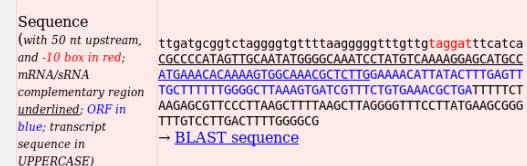

Prodictod 2D
structure PDE PNC
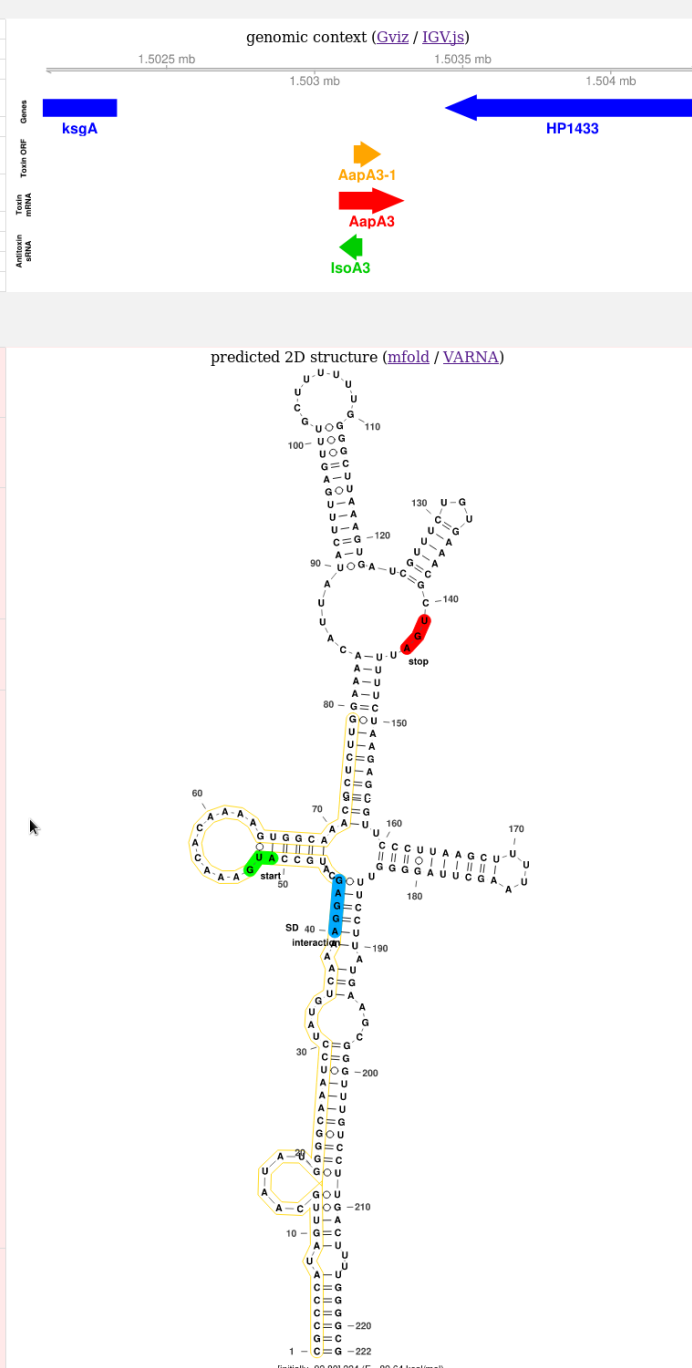

(1)

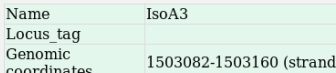

Length
Sequence

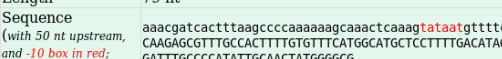

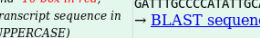

Predictede 2D
structure

Toxin Peptide

Name

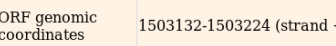

ORF length
(peptice length) $93 \mathrm{nt}$ (30 aa)

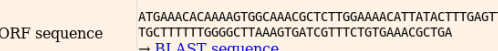

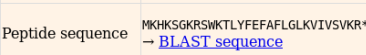

Predicted $2 \mathrm{D}$
structure

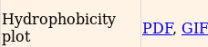

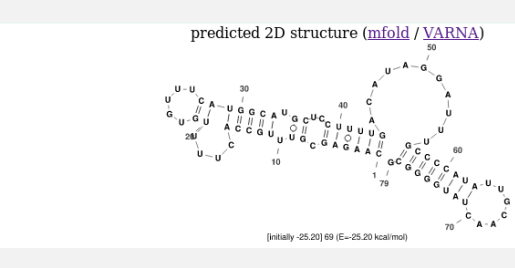

predicted 2D Structure (PSIPRED / POLIYVVIEW-2D) MKHKSGKRSWKTLYYFEEAFLGLKVIVSVRR

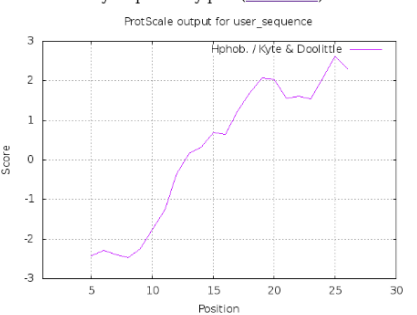

zoLAB INSERM U1212, CNRS UMR5320, University of Borddaux

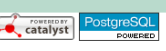

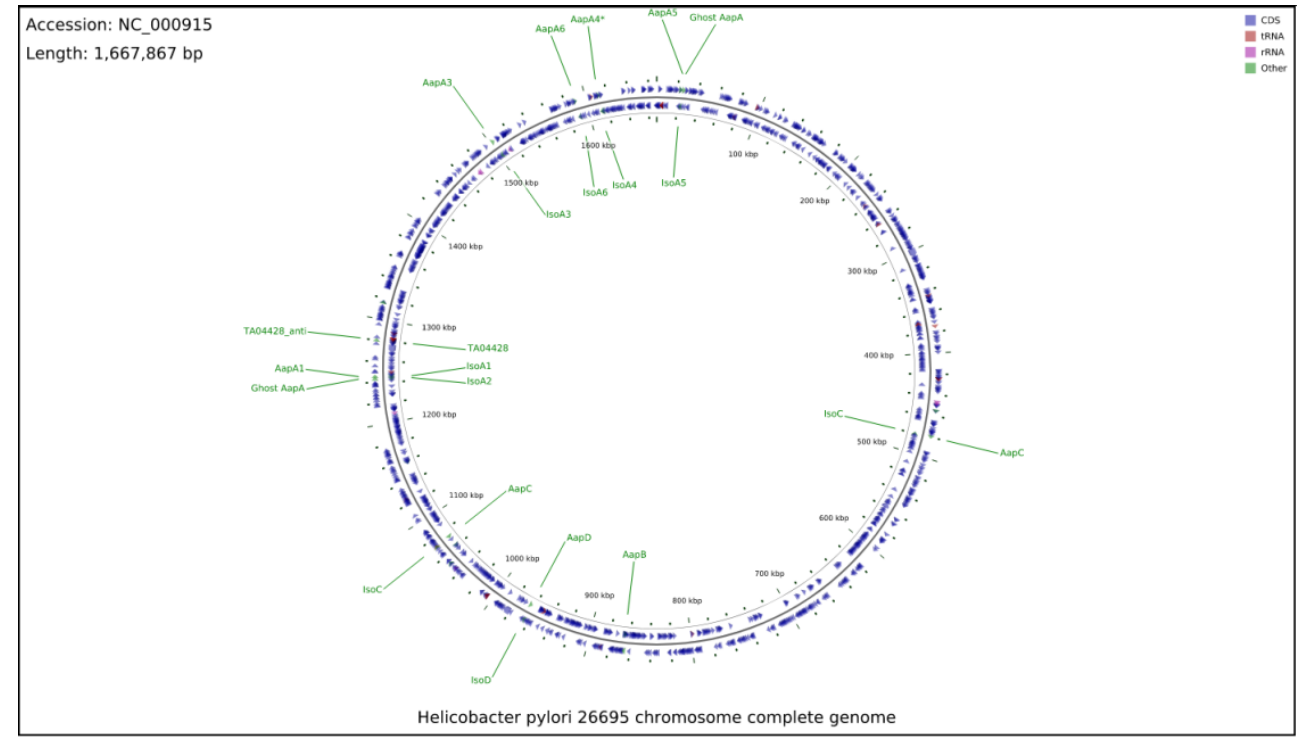

Fig. 2 
Fig. 3A

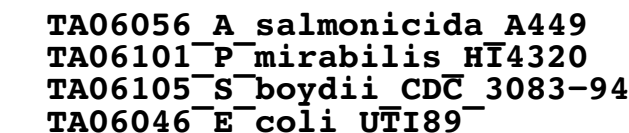

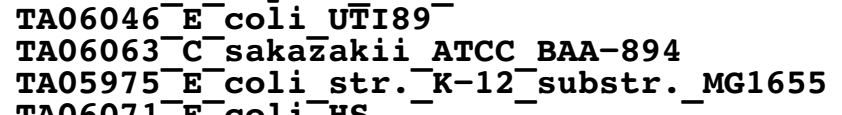

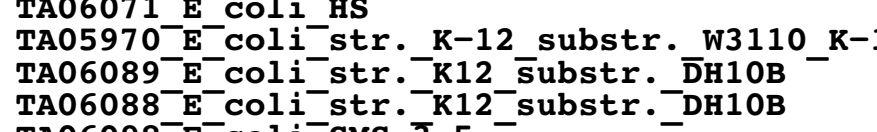

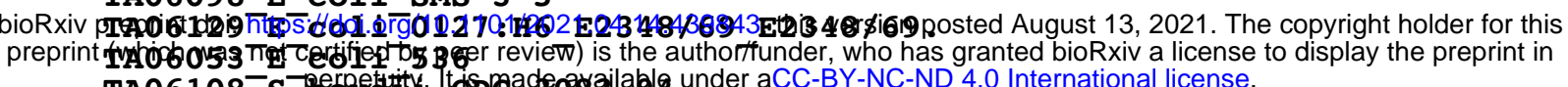

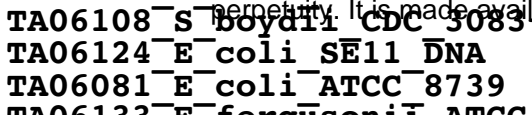

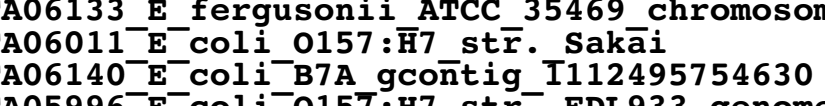

$\begin{array}{ll} & \\ & \end{array}$

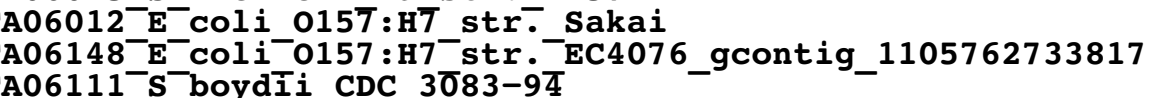

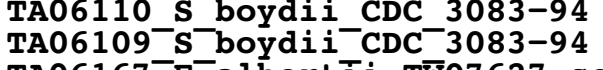

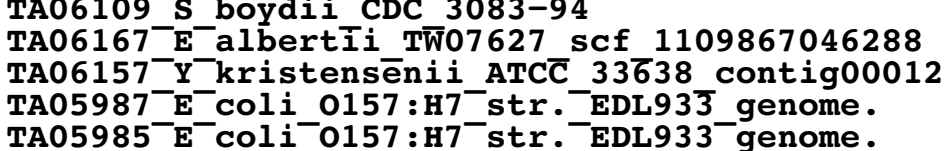

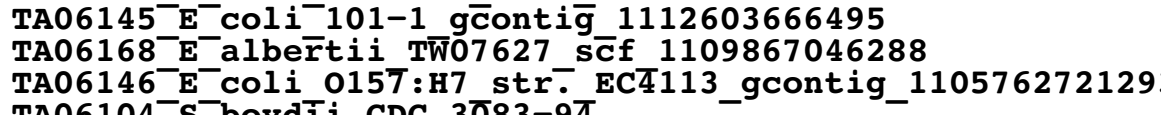

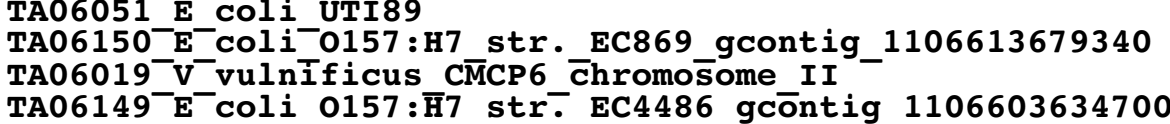

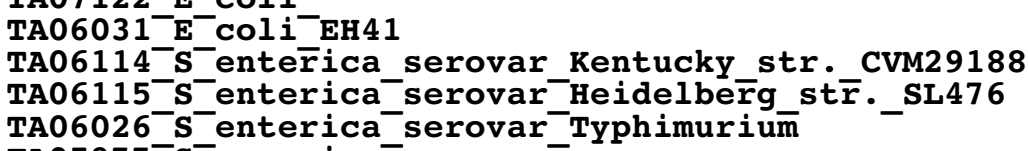

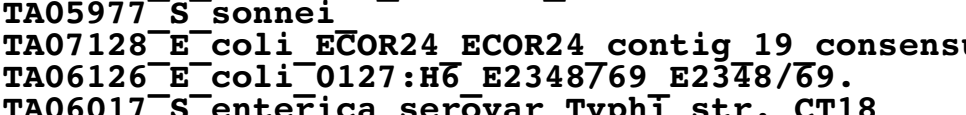

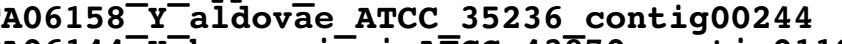

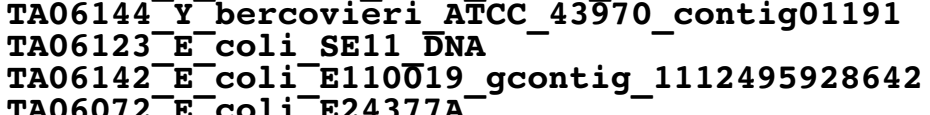

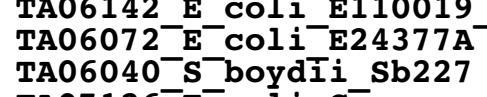

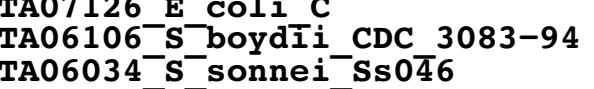

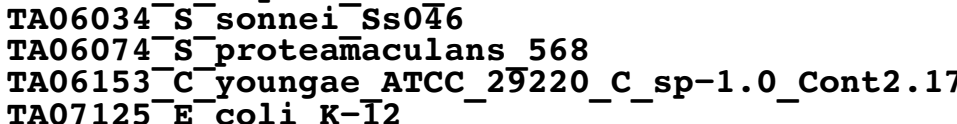

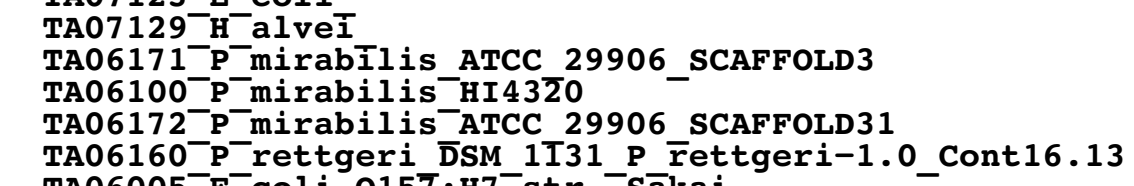

- erogenuss-1.1._cont 1.4

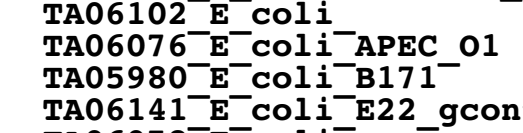

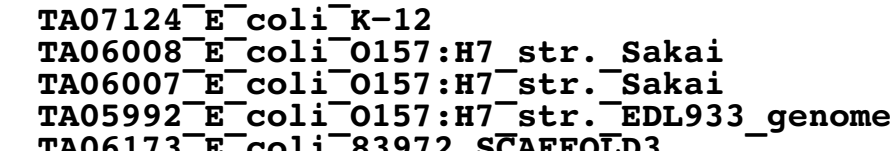

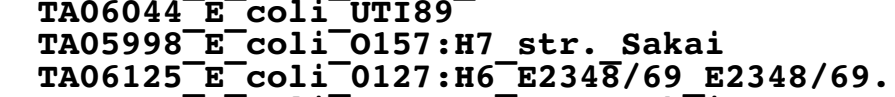

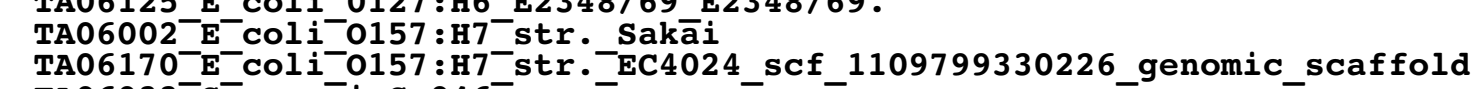

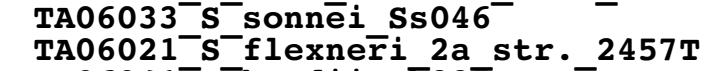

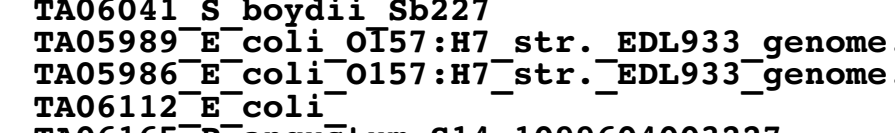

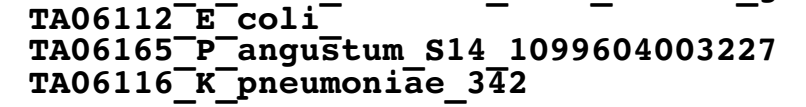

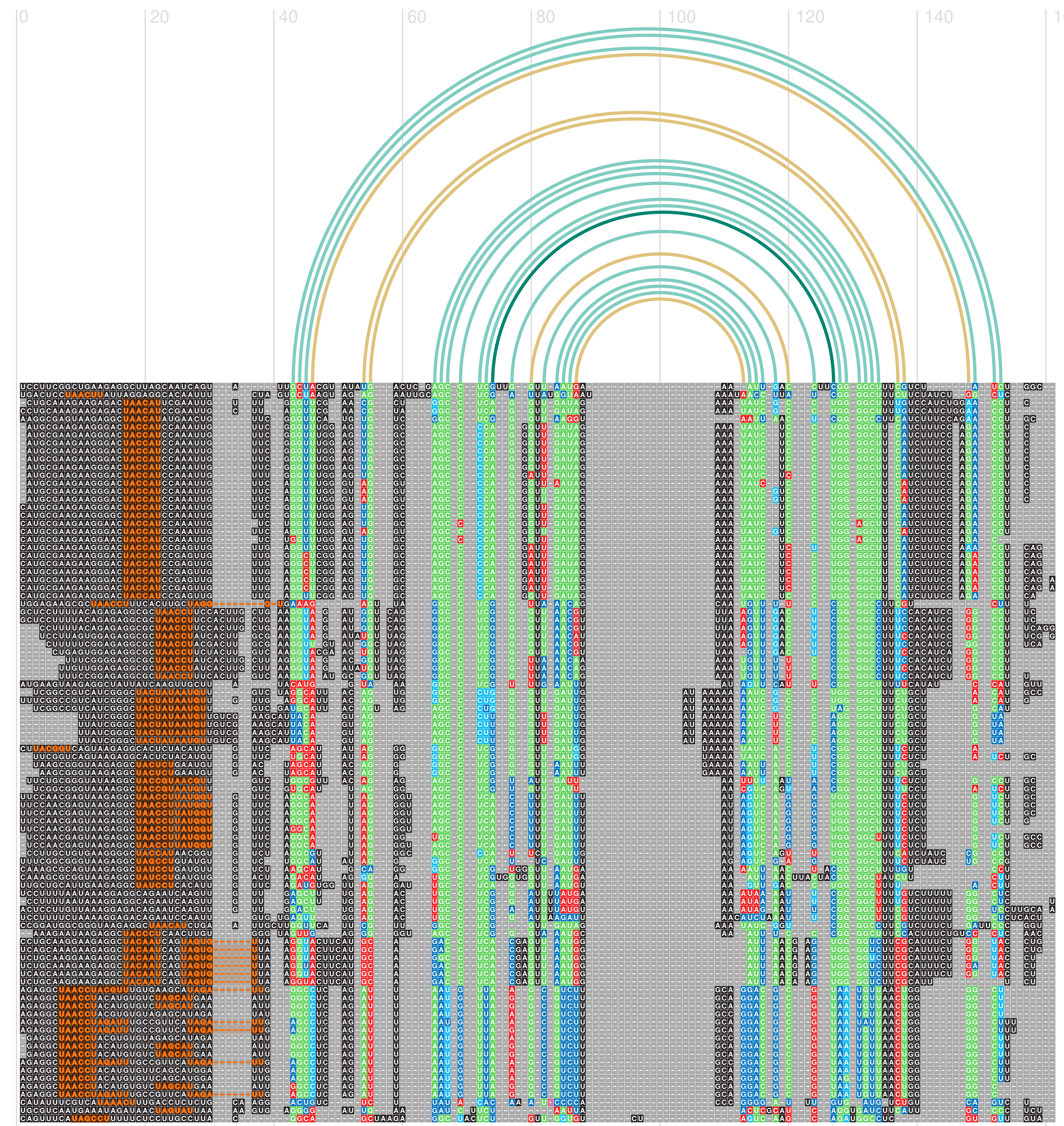


Fig. 3B

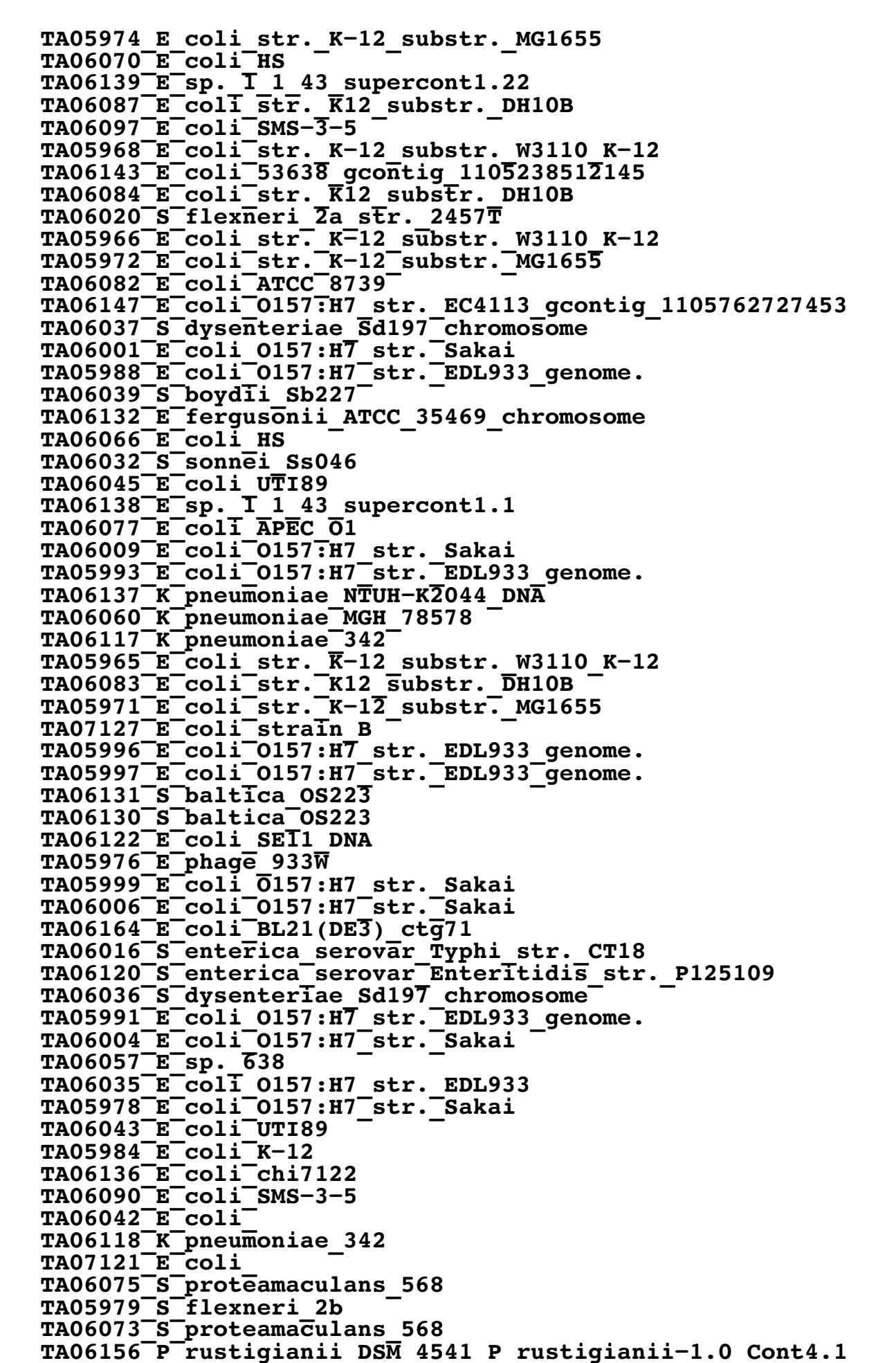

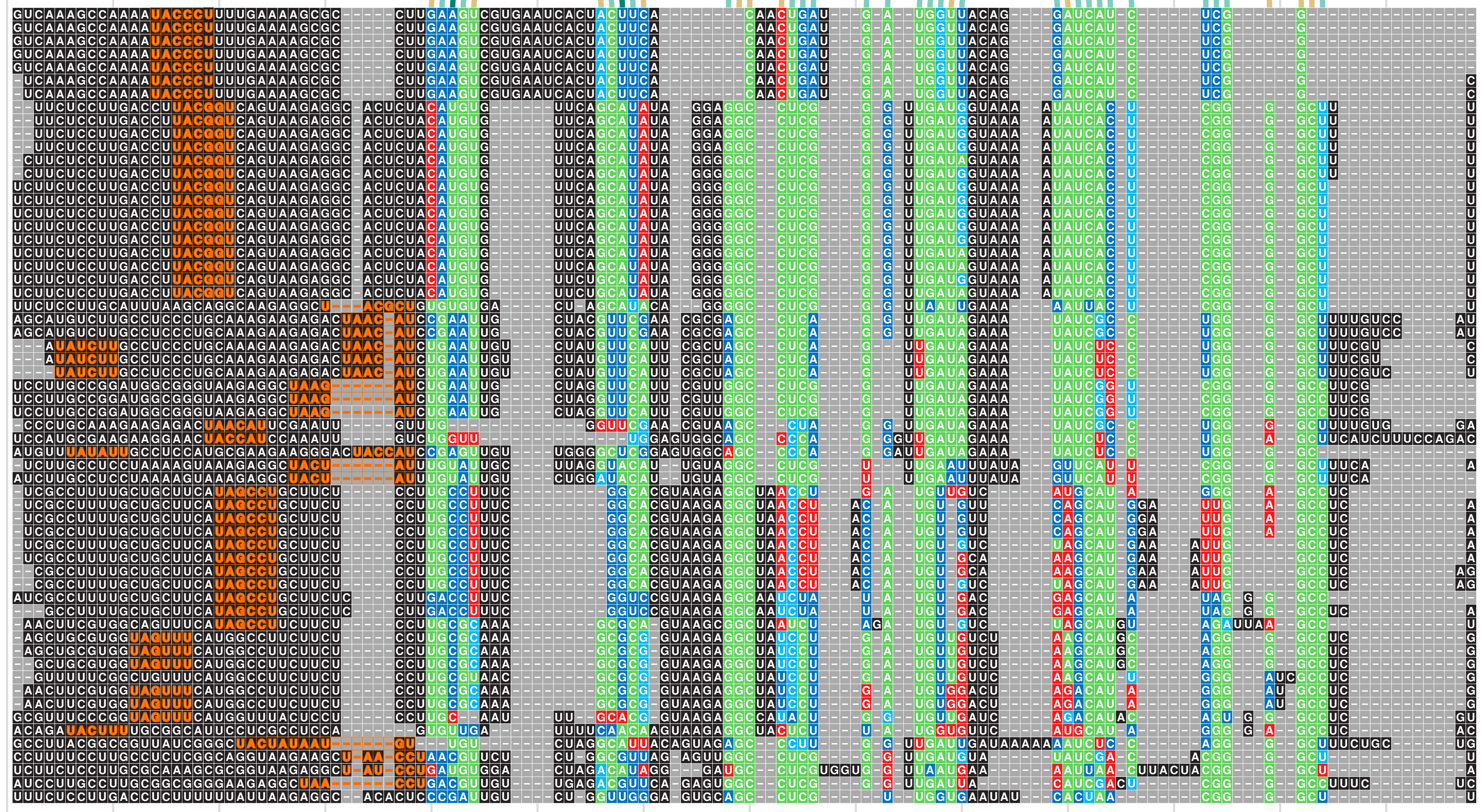

